\title{
OPEN Author Correction: Iron acquisition system of Sphingobium sp. strain SYK-6, a degrader of lignin-derived aromatic compounds
}

\section{Masaya Fujita, Taichi Sakumoto, Kenta Tanatani, HongYang Yu, Kosuke Mori, Naofumi Kamimura \& Eiji Masai $(i)$}

Correction to: Scientific Reports https://doi.org/10.1038/s41598-020-68984-2, published online 22 July 2020

This Article contains an error in Table 1 in the Locus Tag column where,

“SLG_14330(tonB1)”.

should read:

“SLG_14430(tonB1)".

\begin{abstract}
(c) (i) Open Access This article is licensed under a Creative Commons Attribution 4.0 International License, which permits use, sharing, adaptation, distribution and reproduction in any medium or format, as long as you give appropriate credit to the original author(s) and the source, provide a link to the Creative Commons licence, and indicate if changes were made. The images or other third party material in this article are included in the article's Creative Commons licence, unless indicated otherwise in a credit line to the material. If material is not included in the article's Creative Commons licence and your intended use is not permitted by statutory regulation or exceeds the permitted use, you will need to obtain permission directly from the copyright holder. To view a copy of this licence, visit http://creativecommons.org/licenses/by/4.0/.
\end{abstract}

(C) The Author(s) 2020 